Hak Cipta Dilindungi Undang-Undang

1. Dilarang mengutip sebagian atau seluruh karya tulis ini tanpa mencantumkan dan menyebutkan sumber:

a. Pengutipan hanya untuk kepentingan pendidikan, penelitian, penulisan karya ilmiah, penyusunan laporan, penulisan kritik atau tinjauan suatu masalah.

b. Pengutipan tidak merugikan kepentingan yang wajar Unand.

2. Dilarang mengumumkan dan memperbanyak sebagian atau seluruh karya tulis ini dalam bentuk apapun tanpa izin Unand.

\title{
PENGGUNAAN SnO2 DAN TiO2 ANATASE SEBAGAI KATALIS DEGRADASI CARBARYL SECARA OZONOLISIS SERTA PENDETEKSIANNYA MENGGUNAKAN SPEKTROFOTOMETER UV-VIS DAN HPLC
}

\section{SKRIPSI}

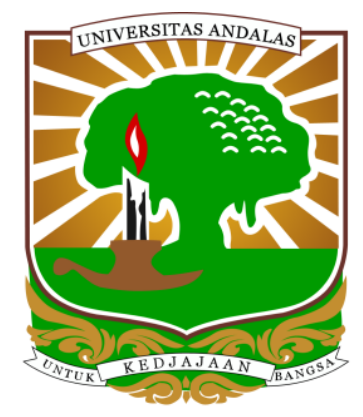

SANDRA TRI JULI FENDRI

07132068

JURUSAN KIMIA

FAKULTAS MATEMATIKA DAN ILMU PENGETAHUAN ALAM UNIVERSITAS ANDALAS

PADANG 2011 


\section{KATA PENGANTAR.}

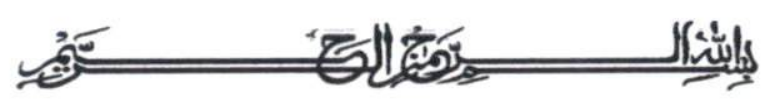

Segala puji bagi Allah SWT yang telah melimpahkan segala rahmat dan hidayahNya sehingga dengan kerja keras penulis dapat menyelesaikan penelitian dan penyusunan skripsi yang berjudul "Penggunaan $\mathrm{SnO}_{2}$ dan $\mathrm{TiO}_{2}$-anatase Sebagai Katalis Degradasi Carbaryl Secara Ozonolisis serta Pendeteksiannya Menggunakan Spektrofotometer UV-Vis dan HPLC". Penyusunan skripsi ini merupakan suatu syarat untuk memperoleh gelar Sarjana Sains (Strata 1) pada Jurusan Kimia, Fakultas Matematika dan Ilmu Pengetahuan Alam, Universitas Andalas. Dalam pelaksanaan penelitian maupun penyusunan skripsi ini penulis mendapatkan banyak masukan, bantuan dan bimbingan dari berbagai pihak yang sangat bermanfaat baik secara langsung maupun tidak langsung. Oleh karena itu, pada kesempatan ini penulis ingin menyampaikan terima kasih kepada Ibu Prof. Dr. Safni, M.Eng sebagai pembimbing I dan Bapak Prof. Dr. Hamzar Suyani, M.Sc sebagai pembimbing II. Kemudian penulis juga memberikan terima kasih kepada:

1. Kedua orang tua yang telah memberikan dukungan yang tiada batasnya baik moril, maupun materil.

2. Bapak Dr. Adlis Santoni sebagai Ketua Jurusan Kimia dan Bapak Dr. Mai Efdi sebagai Koordinator Pendidikan Jurusan Kimia FMIPA UNAND.

3. Ibu Yefrida, M.Si sebagai Pembimbing Akademik yang telah memberikan bimbingan, arahan serta dukungan selama penulis menempuh pendidikan di Jurusan Kimia FMIPA UNAND

4. Bapak-bapak dan Ibu-ibu dosen Jurusan Kimia yang telah memberikan ilmu dan pengetahuan bagi penulis

5. Bapak-Bapak dan Ibu-ibu pegawai tata usaha Jurusan Kimia yang telah membantu urusan administrasi dan kelengkapan selama ini.

6. Semua analis di labarotorium Kimia FMIPA yang telah mendukung kelancaran penelitian. 


\section{DAFTAR ISI}

LEMBAR PENGESAHAN................................................................ i

KATA PENGANTAR ....................................................................... iv

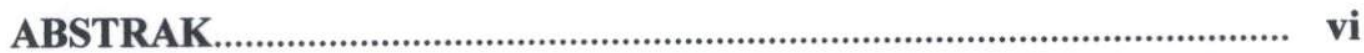

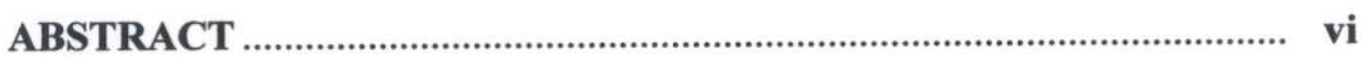

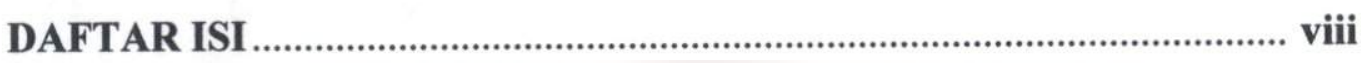

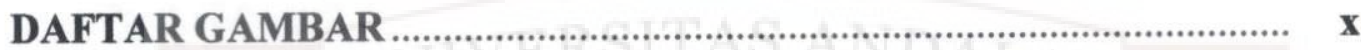

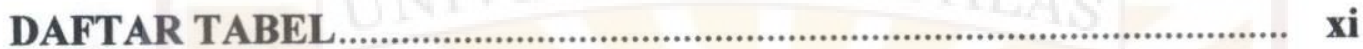

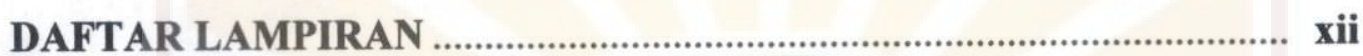

BAB I. PENDAHULUAN .................................................................. 1

1.1 Latar Belakang ....................................................................................... 1

1.2 Perumusan masalah ................................................................................. 3

1.3 Tujuan Penelitian...................................................................................... 3

1.4 Manfaat Penelitian.................................................................................. 3

BAB II. TINJAUAN PUSTAKA …....................................................... 1

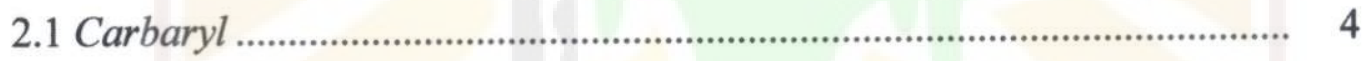

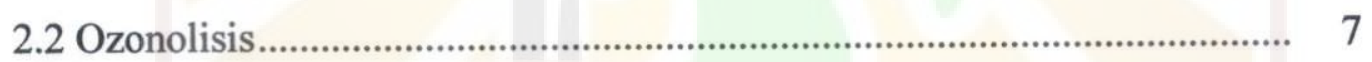

2.3 Timah Dioksida ................................................................................... 8

2.4 Titanium Dioksida................................................................................. 7

2.5 Spektrovotometer UV-Vis................................................................ 10

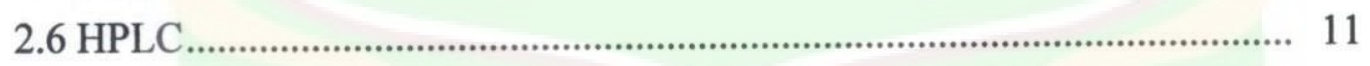

BAB III. METODELOGI PENELITIAN ........................................... 15

3.1 Tempat dan Waktu Penelitian ................................................................ 15

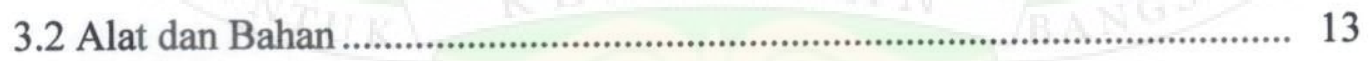

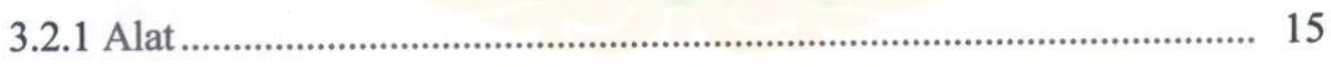

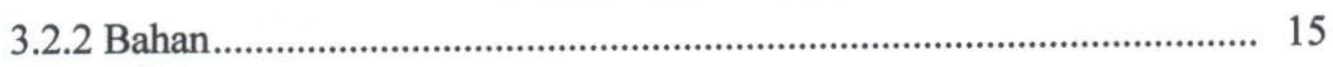

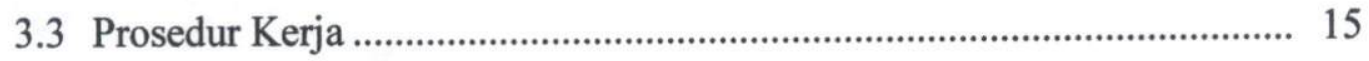

3.3.1 Pembuatan Variasi Pelarut ................................................................ 15

3.3.2 Pembuatan Larutan Carbaryl 100mg/L ........................................... 16

3.3.3 Pengukuran Spektrum Serapan Carbaryl .......................................... 16

3.3.4 Pengaruh Waktu Ozonolisis terhadap persen degradasi...................... 16 
3.3.5 Pengaruh Waktu Ozonolisis terhadap persen degradasi dengan penambahan $\mathrm{SnO} 2$............................................................................. 16

3.3.6 Pengaruh Waktu Ozonolisis terhadap persen degradasi dengan penambahan $\mathrm{TiO}_{2}$-anatase ............................................................. 16

3.3.7 Pengukuran Spektrum Serapan Setelah Ozonolisis .......................... 17

3.3.8 Analisis Hasil Degradasi Senyawa Carbaryl Menggunakan HPLC .... 17

BAB IV HASIL DAN PEMBAHASAN ...................................................... 18

4.1 Pembuatan Variasi pelarut Etanol : Aquades ............................................ 18

4.2 Pengukuran Spektrum Serapan Carbaryl ............................................... 19

4.3 Pengaruh Waktu Ozonolisis Terhadap Presentase Degradasi Carbaryl ... 20

4.4 Pengaruh Waktu Ozonolisis terhadap persen degradasi dengan penambahan $\mathrm{SnO}_{2}$......................................................................... 21

4.5 Pengaruh Waktu Ozonolisis terhadap persen degradasi dengan penambahan $\mathrm{TiO}_{2}$-anatase .................................................................... 22

4.6 Efektifitas Waktu Ozonolisis Tanpa Penambahan Katalis, Dengan Penambahan Katalis $\mathrm{SnO}_{2}$ dan $\mathrm{TiO}_{2}$-anatase Dalam Mendegradasi Senyawa Carbaryl.............................................................................. 23

4.7 Pengukuran Spektrum Serapan Carbaryl setelah ozonolisis .................... 26

4.8 Analisis Hasil Degradasi Carbaryl Secara Ozonolisis dengan menggunakan HPLC ....................................................................... 27

BAB V. KESIMPULAN DAN SARAN 30

5.1 Kesimpulan....................................................................................... 30

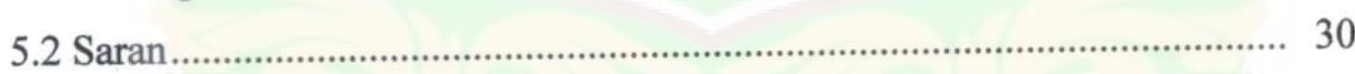

DAFTAR PUSTAKA $\quad 31$

LAMPIRAN 33 


\section{DAFTAR GAMBAR}

Gambar 1. Struktur Carbaryl ................................................................. 4

Gambar 2. Tahapan degradasi senyawa Carbaryl ......................................... 5

Gambar 3. Reaksi degradasi menggunakan ozon .........................................6

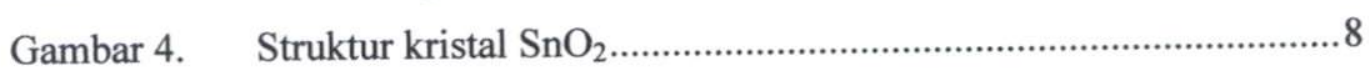

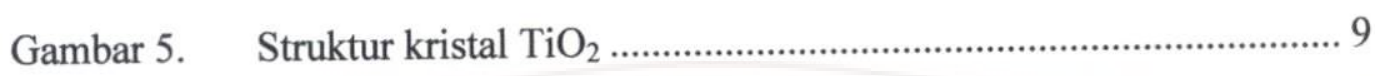

Gambar 6. Skema alat HPLC secara umum .................................................12

Gambar 7. Spektrum serapan Carbaryl dalam Pelarut Etanol : Akuades

Pada variasi kosentrasi a) $10 \mathrm{ppm}$ b) $20 \mathrm{ppm} \mathrm{c)} 30 \mathrm{ppm} \mathrm{d)} 40$ ppm e) $50 \mathrm{ppm}$........................................................................... 19

Gambar 8. Kurva kalibrasi standar Carbaryl ............................................. 20

Gambar 9. Pengaruh waktu ozonolisis terhadap persen degradasi Carbaryl $\quad 20 \mathrm{mg} / \mathrm{L}$ (waktu $15,30,45,60,75,90$ menit)

Gambar 10. Pengaruh waktu ozonolisis terhadap presentase degradasi carbaryl dengan penambahan katalis $\mathrm{SnO}_{2}$, [Carbaryl] 20 $\mathrm{mg} / \mathrm{L}, \mathrm{SnO}_{2} 0$ dan $10 \mathrm{mg}$

Gambar 11. Pengaruh waktu ozonolisis terhadap presentase degradasi carbaryl dengan penambahan katalis $\mathrm{TiO}_{2}$-anatase , [Carbaryl] $20 \mathrm{mg} / \mathrm{L}, \quad \mathrm{TiO}_{2}$-anatase 0 dan $10 \mathrm{mg}$. .23

Gambar 12. Pengaruh waktu ozonolisis terhadap persen degradasi carbaryl $20 \mathrm{mg} / \mathrm{L}$. a) tanpa penambahan katalis, b) Dengan penambahan katalis $\mathrm{SnO}_{2}$, c) dengan penambahan katalis $\mathrm{TiO}_{2}$-anatase

Gambar 13. Spektrum serapan carbaryl pada waktu optimum dengan spektrofotometer UV-Vis. a) awal b) dengan penambahan $\mathrm{SnO}_{2}$ c) dengan penambahan $\mathrm{TiO}_{2}$-anatase .26

Gambar 14. Hasil Pengukuran Carbaryl Pada Waktu Optimum dengan HPLC. a) awal, b) setelah penambahan $\mathrm{SnO}_{2}$, c) setelah penambahan $\mathrm{TiO}_{2}$-anatase 


\section{DAFTAR LAMPIRAN}

Lampiran 1. Perhitungan penentuan absorbtivitas Molar ( $(\varepsilon)$

33

Lampiran 2. Data absorban dan perhitungan persentase degradasi carbaryl $\quad 20 \mathrm{mg} / \mathrm{L}$ berdasarkan pengaruh waktu ozonolisis

Lampiran 3. Data absorban dan perhitungan persentase degradasi carbaryl $\quad 20 \mathrm{mg} / \mathrm{L}$ berdasarkan pengaruh waktu ozonolisis dengan penambahan $10,0 \mathrm{mg} \mathrm{\textrm {SnO } _ { 2 }}$...............................................37

Lampiran 4. Data absorban dan perhitungan persentase degradasi carbaryl $\quad 20 \mathrm{mg} / \mathrm{L}$ berdasarkan pengaruh waktu ozonolisis dengan penambahan $10,0 \mathrm{mg} \mathrm{TiO}_{2}$-anatase. 


\section{BAB I \\ PENDAHULUAN}

\subsection{Latar Belakang}

Perkembangan yang pesat dibidang Ilmu pengetahuan dan teknologi pada saat sekarang ini telah memacu manusia untuk dapat memenuhi segala kebutuhan hidup dalam upaya mencapai suatu keselamatan, jaminan, dan kualitas hidup yang tinggi. Akan tetapi timbul berbagai permasalahan lingkungan akibat aktivitas manusia dalam upaya pemenuhan kebutuhannya, salah satunya adalah meluasnya penggunaan pestisida yang dapat menimbulkan dampak negatif baik langsung maupun tidak langsung bagi kesehatan manusia dan lingkungan di sekitarnya.

Pestisida merupakan salah satu hasil teknologi modern yang mempunyai peranan penting dalam peningkatan kesejahteraan rakyat. Penggunaan pestisida perlu dikelola sedemikian rupa, sehingga manfaatnya dapat dioptimalkan dan efek samping yang membahayakan dapat ditekan sekecil mungkin.

Berdasarkan Peraturan Pemerintah No 7 tahun 1973 yang dimaksud dengan pestisida adalah semua zat kimia dan bahan lain serta jasad renik dan virus yang digunakan untuk memberantas atau mencegah hama dan penyakit yang merusak tanaman atau hasil pertanian, memberantas gulma, membunuh atau mengendalikan berbagai hama yang dianggap merugikan atau penyakit yang merusak bagian tanaman atau hasil pertanian. Untuk itu penggunaan pestisida yang tidak bijaksana, jelas akan menimbulkan efek samping bagi kesehatan manusia, sumber daya hayati dan lingkungan pada umumnya ${ }^{1}$.

Penggunaan senyawa organik sintetik memberikan dampak yang negatif terhadap pencemaran lingkungan. Pencemaran senyawa organik baik itu biodegradable maupun non-biodegradable mempunyai sifat racun, apalagi senyawa non-biodegradable yang bersifat karsinogen. Senyawa organik non-biodegradable yang berasal dari limbah budidaya pertanian adalah herbisida, insektisida, fungisida dan rodentisida. 
Carbaryl merupakan bahan aktif yang terkandung dalam salah satu jenis insektisida yang dijual dengan merek dagang Sevin $85 \mathrm{~S}$. Senyawa ini digunakan untuk mengendalikan hama pada tanaman kacang tanah, jagung, kapas, kedelei, kelapa, kelapa sawit, kopi, teh, tebu, lada dan tembakau. Luasnya penggunaan senyawa Carbaryl dibidang pertanian akan menyebabkan semakin banyaknya residu senyawa ini yang terakumulasi di lingkungan.

Pengolahan limbah dengan metoda konvensional telah dilakukan dengan cara klorinasi, pengendapan, dan penyerapan oleh karbon aktif, kemudian lumpur atau sludge yang terbentuk dibakar atau diproses secara mikrobiologi. Pembakaran sludge akan mengakibatkan terbentuknya senyawa klorosida dan karbon dioksida, sedangkan penggunaan karbon aktif hanya menyerap pencemar organik yang bersifat non-polar dengan berat molekul rendah, sedangkan untuk senyawa non polar dengan berat molekul tinggi tidak tereliminasi. Proses mikrobiologi hanya dapat menguraikan senyawa biodegradable, sedangkan senyawa non-biodegradable tetap berada dalam sludge yang akan kembali ke lingkungan, akibatnya terjadi akumulasi senyawa tersebut dialam ${ }^{1}$. Hal ini menjelaskan bahwa pemurnian air limbah dengan metoda konvensional hanyalah merupakan penanganan sementara karena tidak merombak kontaminan tetapi hanya merubahnya dari satu bentuk ke bentuk lain. Oleh karena itu perlu dicari metoda alternatif lain yang efektif untuk menguraikan limbah tersebut.

Ozonolisis merupakan suatu metoda degradasi senyawa organik dengan menggunakan ozon $\left(\mathrm{O}_{3}\right)$, dimana terjadi pemutusan antara $\mathrm{C}=\mathrm{C}$ sehingga menghasilkan ikatan rangkap $\mathrm{C}=\mathrm{O}^{2}$. Hasil dari degradasi ini tergantung pada jenis ikatan rangkap yang teroksidasi dan kondisi perlakuan. Dalam fasa air, ozon dapat diuraikan oleh ion hidroksida, $\mathrm{OH}^{-}$, atau basa konjugasi dari $\mathrm{H}_{2} \mathrm{O}_{2}\left(\mathrm{HO}_{2}{ }^{-}\right)$menjadi radikal $\mathrm{HO}_{2}$ dan $\mathrm{OH}$ yang dapat membantu proses degradasi senyawa organik dalam pestisida ${ }^{3}$.

Kajian sekarang yang berkembang saat ini adalah penggunaan $\mathrm{TiO}_{2}$ untuk mendegradasi senyawa organik dalam limbah cair. $\mathrm{TiO}_{2}$-anatase merupakan katalis yang efektif digunakan untuk mendegradasi senyawa-senyawa organik toksik. Hal ini terbukti dari beberapa penelitian seperti rhodamin B terdegradasi $90 \%$ dengan 


$$
\begin{aligned}
& \mathrm{O}_{3}+\mathrm{O}_{2}^{-} \longrightarrow \mathrm{O}_{2}+\mathrm{O}_{3}^{-} \\
& \mathrm{O}_{3}^{-}+\mathrm{H}_{2} \mathrm{O}_{2} \longrightarrow \mathrm{OH}^{-}+\cdot \cdot \mathrm{OH}+\mathrm{O}_{2}
\end{aligned}
$$

Gabungan sonolisis dengan ozonolisis meningkatkan $\cdot \mathrm{OH}$ karena secara termolitik penguraian ozon menjadi $\mathrm{O}_{2}$ dari gelembung kavitasi. Reaksi awal sampai terbentuknya atom oksigen yang bereaksi dengan air untuk membentuk radikal hidroksil, hidrogen peroksida yang dihasilkan dengan reaksi berikut ${ }^{3}$ :

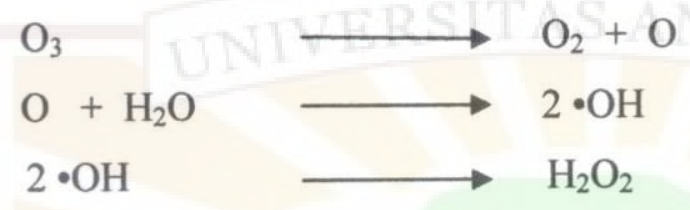

Ozon dapat bereaksi dengan senyawa organik baik langsung atau tidak langsung melalui dekomposisi dan formasi dari radikal hidroksil atau oksidasi dari spesies organik yang mungkin terjadi melalui kombinasi reaksi dengan molekul ozon dan reaksi dengan hidroksi radikal ${ }^{11}$.

Proses ozonolisis melalui reaksi pada ikatan rangkap senyawa organik kompleks menghasilkan dua molekul sederhana yang memiliki bentuk dan karekteristik molekul yang berbeda. Jika bereaksi dengan senyawa lain, maka ozon akan menghancurkan senyawa tersebut. Proses akhir jika molekul organik bereaksi dengan ozon adalah karbon dioksida dan air ${ }^{12}$.

Ozon merupakan oksidator kuat dengan potensial oksidasi 2,8 eV. Ozon memiliki kereaktifan kimia yang tinggi karena memiliki konfigurasi elektron yang stabil. Ozon sangat efektif untuk pengolahan air minum dan pengolahan dan pengolahan air limbah karena ozon memiliki potensial oksidasi yang tinggi. Ozon dapat mendegradasi residu pestisida seperti metal-parathion, parathion, diazion, dan sipermethrin. Mekanisme degradasi disebabkan karena adanya radikal $\mathrm{OH}$ yang merusak senyawa organik tersebut ${ }^{13}$.

\subsection{Timah Dioksida ( $\mathrm{SnO}_{2}$ )}

Timah dioksida merupakan salah satu semikonduktor dengan band gap (Eg) $3,6 \mathrm{eV}$. Ditemui dalam bentuk mineral kasiterit, memiliki berat molekul 150,71 $\mathrm{g} / \mathrm{mol}$, berbentuk bubuk bewarna putih, titik leleh $1630^{\circ} \mathrm{C}$, titik lebur $1800-1900{ }^{\circ} \mathrm{C}$, 
struktur kristal rutile (tetragonal), timah oksida tidak larut dalam air tetapi larut dalam asam, dapat dihasilkan melalui logam timah yang dioksidakan pada titik lebur yang tinggi ${ }^{14}$.

$\mathrm{SnO}_{2}$ merupakan suatu senyawa ionik, non-stoikiometri, karena ada cacat titik yang berupa kelebihan atom logam $\mathrm{Sn}$ (Stannic). $\mathrm{SnO}_{2}$ banyak dimanfaatkan untuk berbagai aplikasi karena stabil terhadap perlakuan panas, biaya pendeposisiannya yang relatif murah, dan sifat physicochemical yang baik. Struktur kristal $\mathrm{SnO}_{2}$ dapat dilihat pada gambar 4 .

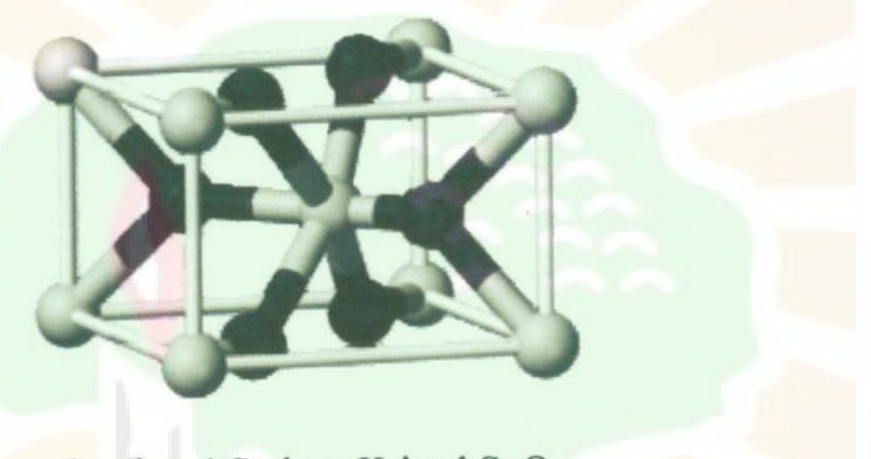

Gambar 4.Stuktur Kristal $\mathrm{SnO}_{2}$

$\mathrm{SnO}_{2}$ memiliki struktur kristal rutile dimana setiap 1 atom $\mathrm{Sn}$ berkoordinasi dengan 6 atom oksigen. $\mathrm{SnO}_{2}$ tidak larut dalam air akan tetapi larut dalam asam dan basa kuat.

$\mathrm{SnO}_{2}$ berupa bahan semi konduktor tipe-n dengan lebar celah energy lebar, yaitu lebih besar dari 3,0 eV. $\mathrm{SnO}_{2}$ bersifat non polar dengan parameter kisi a =4,738 $\AA$ dan $\mathrm{c}=3,1888 \AA^{14}$.

\subsection{Titanium Dioksida}

Titanium dioksida $\left(\mathrm{TiO}_{2}\right)$ dikenal sebagai semikonduktor tipe-n yang memiliki celah energi relatif besar dengan sifat super hidrofilik ketika terkena cahaya. $\mathrm{TiO}_{2}$ merupakan senyawa dioksida berwana putih yang tahan karat dan tidak beracun. $\mathrm{TiO}_{2}$ seiring digunakan sebagai katalis untuk dekomposisi senyawa-senyawa organik toksik seperti pestisida, zat warna dan lain-lain. $\mathrm{TiO}_{2}$ biasanya terdapat dalam bentuk 
powder atau lapisan tipis, bersifat amfoter dan sulit larut dalam air. Berat molekulnya $79,90 \mathrm{~g} / \mathrm{mol}$ dimana kadar $\mathrm{Ti} 59,95 \%$ dan kadar $\mathrm{O} 40,05$. Titik leleh dari $\mathrm{TiO}_{2}$ adalah $1870^{\circ} \mathrm{C}$. $\mathrm{TiO}_{2}$ tidak larut dalam $\mathrm{HCl}, \mathrm{HNO}_{3}$, dan $\mathrm{H}_{2} \mathrm{SO}_{4}$ encer, tetapi larut dalam $\mathrm{H}_{2} \mathrm{SO}_{4}$ pekat. $\mathrm{TiO}_{2}$ merupakan salah satu katalis yang paling stabil, paling sering digunakan dibandingkan dengan katalis lainnya. $\mathrm{TiO}_{2}$ mempunyai sifat inert dan baik secara biologi maupun secara kimia, stabil dan tahan terhadap korosi kimia selama reaksi berlangsung serta relatif tidak mahal ${ }^{15}$.

$\mathrm{TiO}_{2}$ memiliki tiga macam struktur kristal yaitu anatase (tetragonal), rutile (tetragonal), dan brookite (ortorombik). Gambar 5 menunjukkan struktur kristal rutile, anatase, dan brookite.

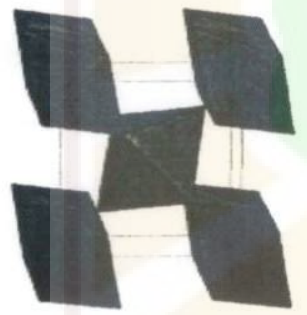

Kristal rutile

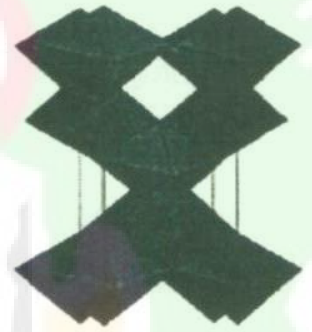

Kristal anatase

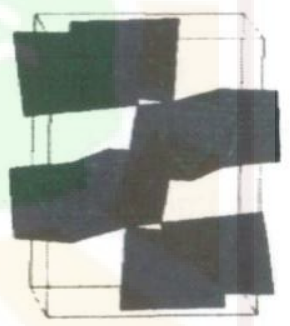

Kristal brookite

Gambar 5. Struktur Kristal $\mathrm{TiO}_{2}$

Perbedaan struktur kristal $\mathrm{TiO}_{2}$ mengakibatkan perbedaan tingkat energi struktur pita elektroniknya. Tingkat energi hasil hibridisasi yang berasal dari kulit $3 \mathrm{~d}$ titanium bertindak sebagai pita konduksi sedangkan tingkat energi hasil hibridisasi dari kulit $2 p$ oksigen bertindak sebagai pita valensi. Konsekuensinya posisi tingkat energi pita valensi, pita konduksi dan besarnya energi gap akan berbeda bila lingkungan atau penyusun atom $\mathrm{Ti}$ dan $\mathrm{O}$ di dalam kristal $\mathrm{TiO}_{2}$ berbeda seperti pada struktur anatase $(\mathrm{Eg}=3,2 \mathrm{eV})$ dan rutile $(\mathrm{Eg}=3,0 \mathrm{eV})^{16}$.

$\mathrm{TiO}_{2}$ merupakan katalis yang paling cocok digunakan untuk degradasi senyawa organik, karena $\mathrm{TiO}_{2}$ paling aktif dan praktis untuk diaplikasikan dalam 
logam alkali atau logam alkoksida atau dari logam lain yang dilapisi dengan alkali, karena logam alkali atau alkoksidanya mudah melepaskan elektron. Jendela kuarsa digunakan untuk melewatkan melewatkan cahaya dari sumber radiasi. Detektor yang sering digunakan adalah photomultipliertube atau photodiodaarray ${ }^{20}$.

Radiasi elektromagnetik UV-Vis tersebut mempunyai panjang gelombang berkisar 200-800 nm. Sumber UV mulai dari 200-400 nm dan sinar tampak 400-800 nm. Absorpsi radiasi akan menyebabkan terjadinya eksitasi elektron. Atom atau molekul akan mengadsorbsi pada daerah panjang yang energinya sesuai dengan beda energi antara keadaan dasar dan keaadaan tereksitasi dari atom atau molekul.

Untuk pengukuran secara kuantitatif, metoda spektrofotometri UV-Vis diguanakan untuk menentukan kosentrasi larutan, dimana absorbsi sinar oleh larutan merupakan fungsi kosentrasi. Pada kondisi optimum, dapat dibuat hubungan linear secara langsung antara absorbsi larutan dan kosentrasi larutan tersebut. Persamaan yang menggambarkan hubungan linear tersebut dikenal dengan hukum lambert-beer, yaitu : $\mathrm{A}=$ e.b.c, dimana $\mathrm{A}$ merupakan absorban, $\varepsilon$ sebagai serapan spesifik $\left(\mathrm{cm}^{-1} \mathrm{M}^{-1}\right)$, b menunjukkan lajur larutan $(\mathrm{cm})$ dan $\mathrm{c}$ menyatakan kosentrasi $(\mathrm{M})^{19}$.

\subsection{High Performance Liguid Chomatography ( HPLC)}

Kromatografi adalah suatu bagian teknik pemisahan komponen campuran dalam fasa diam oleh fasa gerak. Dalam kromatografi terdapat 3 hal yang berperan penting dalam hal ini yaitu fasa gerak, fasa diam dan analit (sampel yang akan dianalisa). Kromatografi terbagi atas tiga macam seperti kromatografi cair, gas, dan fluida superkritis. Jenis kromatografi dapat digunakan tergantung pada jenis analit yang dianalisa. Pada analisa residu pestisida karbamat kromatografi yang dipakai adalah High Performance Liquid Chromatography (HPLC) atau dikenal juga dengan kromatografi cair kinerja tinggi.

HPLC dapat digunakan untuk sebagian besar senyawa yang tidak menguap dan senyawa yang berbobot molekul tinggi. Selain itu HPLC dapat dipakai untuk senyawa organik, yang sebagian besar tidak menguap. HPLC biasanya dilakukan pada suhu kamar. Senyawa yang tidak tahan panas dapat ditangani dengan mudah ${ }^{21}$. 
Pada sistem HPLC data yang dihasilkan adalah waktu retensi dan area dari sampel. Analisis kualitatif dan kuantitatif dilakukan dengan membandingkan waktu retensi dari luas puncak standar dari senyawa murni.

Metoda HPLC dapat digunakan dalam berbagai lapangan seperti farmasi, biokomia, industri makanan, industri kimia, kimia forensik, laboratorium klinik, laboratorium klinik dan polutan ${ }^{22}$.

Sistem peralatan HPLC pada umumnya terdiri dari pompa, injektor, kolom, detektor, dan integrator ( alat pembaca sinyal yang dihasilkan detektor ), seperti gambar 6.

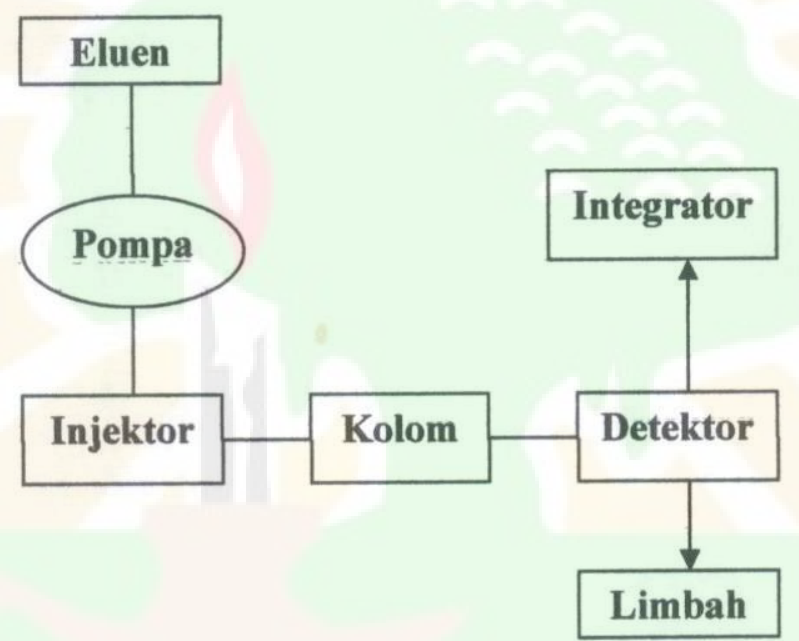

Gambar 6. skema alat HPLC secara umum

Fase diam merupakan reaksi antara klorosilana dengan gugus hidroksil dari silika dimana permukaan silika banyak mengandung gugus hidroksil sekitar $27 \times 10^{27}$ gugus hiroksil $/ \mathrm{m}^{2}$. Fase diam non polar yang paling umum digunakan adalah $\mathrm{C}_{8}$ (oktasilana) dan $\mathrm{C}_{18}$ (oktadesilana). Sebaliknya fasa gerak yang digunakan mempunyai kepolaran yang tinggi. Dalam hal ini dapat digunakan pelarut metanol, asetonitril dan air yang dicampurkan dengan perbandingan tertentu.

Fase gerak yang digunakan dalam metoda HPLC harus mempunyai syaratsyarat tertentu yakni mempunyai tingkat kemurnian yang tinggi, mudah didapatkan, 
titik didih $20-50^{\circ} \mathrm{C}$ di atas temperatur kolom, kekentalan rendah, kurang reaktif, sesuai dengan detektor yang digunakan dan tidak mudah terbakar ${ }^{22}$.

Pemisahan pada HPLC terjadi secara dinamis, oleh sebab itu diperlukan sistem deteksi yang dapat bekerja secara langsung dan menghasilkan rekaman yang yang spontan dari peristiwa-peristiwa yang terjadi pada kolom HPLC. Detektor harus mempunyai sensitifitas yang baik pada kosentrasi rendah dari analit dan volume yang kecil untuk menghindari pelebaran pita.

Detektor UV-Vis adalah detektor yang paling banyak digunakan dalam metoda HPLC karena sebagian besar senyawa organik mengabsorbsi sinar dalam daerah UV dari spektrum elektromagnetik ${ }^{22}$. Pada panjang gelombang ini pelarut sangat sedikit atau sama sekali tidak menyerap sinar, sedangkan analit menyerap dengan kuat. Di samping detektor UV-Vis detektor lain yang digunakan yaitu detektor flouresence, elektrokimia, indeks refraksi, konduktiviti, spektromasa dan FT-IR ${ }^{23}$.

HPLC dengan prinsip kromatografi adsorpsi banyak digunakan digunakan pada industri farmasi dan pestisida. Zat-zat dengan kepolaran yang berbeda, yaitu antara sedikit polar sampai polar dapat dipisahkan dengan HPLC berdasarkan partisi cair-cair. Asam-asam nukleat dapat dipisahkan dengan kolom penukar ion yang dikombinasikan dengan kolom butiran berlapiskan zat berpori. Pemakaian HPLC pada kromatografi eklusi dilakukan dengan kolom panjang, tujuan utama kerjanya tetap sama yaitu penentuan berat molekul polimer dan masalah-masalah biokimia ${ }^{19}$.

Penentuan pestisida biasanya dilakukan dengan metoda kromatografi gas dan kromatografi cair tergantung pada kepolaran, sifat mudah menguap dan resiko terjadi dekomposisi pada temperatur tinggi. Pada umumnya tidak langsung dilakukan karena dalam sampel kandungannya terlalu rendah dan komplek. Beberapa pestisida dari golongan berbeda yang digunakan dalam suatu sampel dapat dianalisis secara langsung dengan HPLC. Pestisida dari golongan karbamat, fosfat, klor, dan piretroid dapat dianalisis secara serentak dengan metoda HPLC mempergunakan kolom $\mathrm{C}_{18}{ }^{24}$.

Pemakaian HPLC ini mempunyai keuntungan yang cukup banyak seperti: analisis dilakukan dalam waktu cepat; daya pisahnya baik; kepekaan terhadap 


\subsubsection{Pembuatan Larutan Carbaryl $100 \mathrm{mg} / \mathrm{L}$}

Untuk membuat larutan Carbaryl $100 \mathrm{mg} / \mathrm{L}$, dilarutkan sebanyak 0,0118 g Sevin $85 \mathrm{~S}$, lalu dimasukkan ke dalam labu ukur $100 \mathrm{ml}$. Encerkan larutan dengan menggunakan pelarut etanol : akuades dengan perbandingan $5: 5$.

\subsubsection{Pengukuran Spektrum Carbaryl.}

Larutan induk Carbaryl $100 \mathrm{mg} / \mathrm{L}$ diencerkan menjadi empat variasi kosentrasi yaitu 10, 20, 30, 40 dan $50 \mathrm{mg} / \mathrm{L}$. Terhadap lima variasi kosentrasi larutan tersebut dilakukan pengukuran spektrum serapan dengan spektrofotometer UV-Vis pada panjang gelombang $200-800 \mathrm{~nm}$.

\subsubsection{Pengaruh Waktu Ozonolisis Terhadap Persentase Degradasi}

Larutan Carbaryl $20 \mathrm{mg} / \mathrm{L}$ sebanyak $20 \mathrm{ml}$ dimasukkan ke dalam erlenmeyer. Selanjutnya diozonolisis pada variasi waktu $(15,30,45,60,75$ dan 90) menit. Selanjutnya dilakukan degradasi dengan mengalirkan ozon ke dalam larutan. Kemudian diukur spektrum serapan masing-masing larutan dengan spektrofotometer UV. Selanjutnya dilakukan perhitungan persentase degradasinya.

\subsubsection{Pengaruh Waktu Ozonolisis Terhadap Persen Degradasi Carbaryl} dengan Penambahan $\mathrm{SnO}_{2}$

Larutan Carbaryl sebanyak $20 \mathrm{ml}$ dengan konsentrasi $20 \mathrm{mg} / \mathrm{L}$ dimasukkan ke dalam erlenmeyer. Kemudian ke dalam larutan ditambahkan 10 mg katalis $\mathrm{SnO}_{2}$. Selanjutnya diozonolisis pada variasi waktu $(15,30,45,60,75$ dan 90) menit. Hasil ozonolisis disentrifus selama 15 menit untuk memisahkan $\mathrm{SnO}_{2}$ dari larutan. Spektrum serapan masing-masing larutan diukur dengan spektrofotometer UV. Selanjutnya dilakukan perhitungan persentase degradasinya.

\subsubsection{Pengaruh Waktu Ozonolisis Terhadap Persen Degradasi Carbaryl dengan Penambahan $\mathrm{TiO}_{2}$-anatase}


Larutan Carbaryl sebanyak $20 \mathrm{ml}$ dengan konsentrasi $20 \mathrm{mg} / \mathrm{L}$ dimasukkan ke dalam erlenmeyer. Kemudian ke dalam larutan ditambahkan 10 mg katalis $\mathrm{TiO}_{2}$ anatase. Selanjutnya diozonolisis pada variasi waktu $(15,30,45,60,75$ dan 90) menit. Hasil ozonolisis disentrifus selama 15 menit untuk memisahkan $\mathrm{TiO}_{2}$-anatase dari larutan. Spektrum serapan masing-masing larutan diukur dengan spektrofotometer UV. Selanjutnya dilakukan perhitungan persentase degradasinya.

Untuk melakukan perhitungan nilai persentase degradasi digunakan persamaan ;

$$
\text { Persentase degradasi }=\frac{\text { A awal }- \text { A akhir }}{\text { A awal }} \times 100 \%
$$

Keterangan :

$\mathrm{A}_{\text {awal }}=$ absorban awal

$\mathrm{A}_{\text {akhir }}=$ absorban akhir

\subsubsection{Pengukuran Spektrum Serapan setelah Ozonolisis Menggunakan}

\section{Spektrofotometer UV-Vis}

Larutan Carbaryl $20 \mathrm{mg} / \mathrm{L}$ awal diukur spektrum serapannya pada panjang gelombang maksimum dengan spektrofotometer UV-Vis. Kemudian Larutan Carbaryl $20 \mathrm{mg} / \mathrm{L}$ pada waktu optimum ozonolisis dengan penambahan $\mathrm{SnO}_{2}$ dan $\mathrm{TiO}_{2}$-anatase diukur spektrum serapannya pada panjang gelombang maksimum yaitu $280 \mathrm{~nm}$ dengan spektrofotometer UV-Vis.

\subsubsection{Pendeteksian Hasil Degradasi Carbaryl Menggunakan HPLC}

Pendeteksian hasil degradasi dan senyawa yang terbentuk setelah terdegradasinya senyawa Carbaryl dilakukan dengan metoda HPLC. Analisis ini dilakukan pada kondisi-kondisi optimum pendegradasian. Pada metoda ini digunakan Fase gerak: metanol : air (3:2), Volume injeksi: $20 \mu \mathrm{L}$, Laju alir: $1 \mathrm{ml} / \mathrm{menit}$, Detektor: UV, Panjang gelombang: $280 \mathrm{~nm}$, Temperatur: $40{ }^{\circ} \mathrm{C}$, Kolom: $\mathrm{C}_{18}$ (Shim-pack VPODS) $250 \times 4,6 \mathrm{~mm}$ id). 


\section{BAB IV}

\section{HASIL DAN PEMBAHASAN}

\subsection{Variasi pelarut Etanol : Akuades}

Pembuatan variasi pelarut digunakan untuk melarutkan Carbaryl, ini disebabkan karena Carbaryl sukar larut dalam air atau akuades saja. Sebelas variasi campuran etanol : akuades dengan perbandingan yang berbeda diujicobakan untuk melarutkan Carbaryl. Dari pengamatan didapatkan hasil sebagai berikut :

Tabel 1. Data Perbandingan variasi pelarut Etanol : Akuades

\begin{tabular}{|c|c|}
\hline $\begin{array}{c}\text { Perbandingan } \\
\text { Pelarut } \\
\text { (Etanol }: \text { Akuades })\end{array}$ & $\begin{array}{c}\text { Warna } \\
\text { Larutan }\end{array}$ \\
\hline $0: 10$ & Keruh \\
\hline $1: 9$ & Keruh \\
\hline $2: 8$ & Keruh \\
\hline $3: 7$ & Keruh \\
\hline $4: 6$ & Keruh \\
\hline $5: 5$ & Bening \\
\hline $6: 4$ & Bening \\
\hline $7: 3$ & Bening \\
\hline $8: 2$ & Bening \\
\hline $9: 1$ & Bening \\
\hline $10: 0$ & Bening \\
\hline
\end{tabular}

Pada variasi pelarut $0: 10,1: 9,2: 8,3: 7$, larutan pestisida yang diencerkan masih keruh. Sedangkan variasi pelarut $5: 5,6: 4,7: 3,8: 2,9: 1$, dan $10: 0$, larutan pestisida dapat larut dan menghasilkan warna bening. Larutan bening ini, kemudian diukur absorbannya menggunakan spektrofotometer UV-Vis, sedangkan larutan yang keruh tadi tidak terukur oleh spektrofotometer UV-Vis. Larutan yang keruh tidak dapat terukur dikarenakan karena larutan keruh tidak dapat meneruskan 
masing senyawa. Berdasarkan hukum Lambert-Beer didapatkan nilai absorptifitas molar rata-rata adalah $6336,53148 \mathrm{~L} \mathrm{~mol}^{-1} \mathrm{~cm}^{-1}$. Perhitungan nilai absorptifitas molar ini dan absorban Carbaryl dalam pelarut akuades : etanol dapat dilihat pada Lampiran 1.

Hubungan yang linear antara kosentrasi yang linear antara kosentrasi Carbaryl dengan absorban dapat dilihat pada Gambar 8. Dalam penelitian selanjutnya digunakan larutan Carbaryl $20 \mathrm{mg} / \mathrm{L}$ sebagai larutan yang akan di ozonolisis.

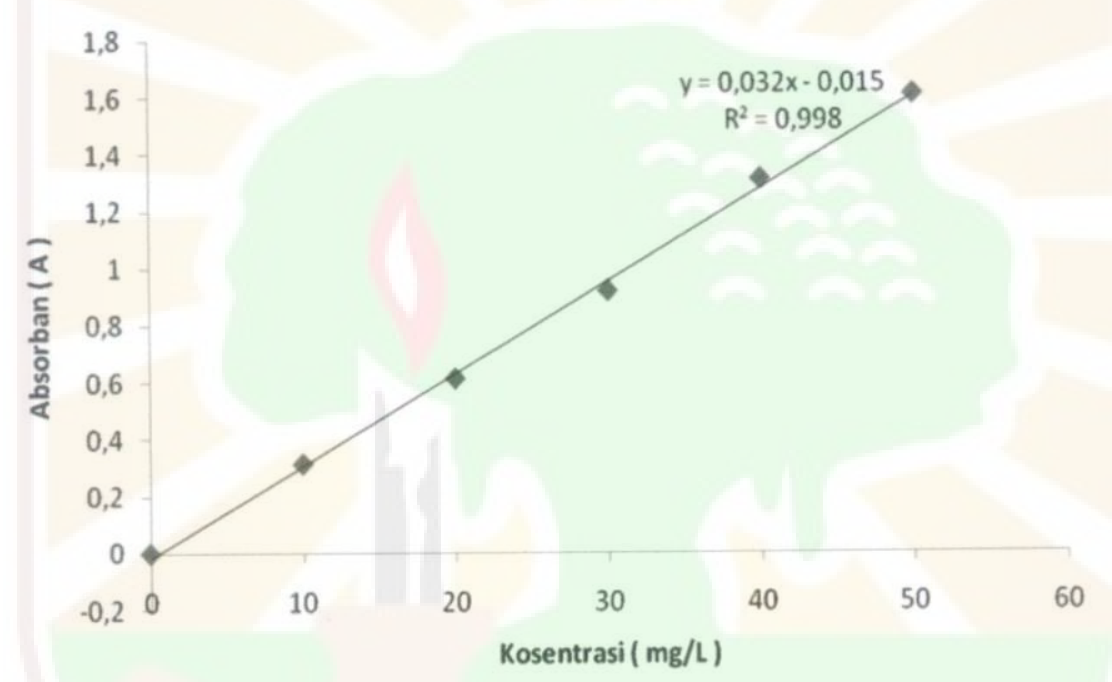

Gambar 8. Kurva kalibrasi standar Carbaryl

\subsection{Pengaruh Waktu Ozonolisis Terhadap Presentase Degradasi Carbaryl}

Penentuan waktu terhadap persentase degradasi Carbaryl dilakukan dengan metoda ozonolisis. Dimana larutan Carbaryl $20 \mathrm{mg} / \mathrm{L}$ dialirkan ozon selama 15, 30, $45,60,75$, dan 90 menit. Pengaruh waktu ozonolisis terhadap persen degradasi Carbaryl dapat dilihat pada Gambar 9. 


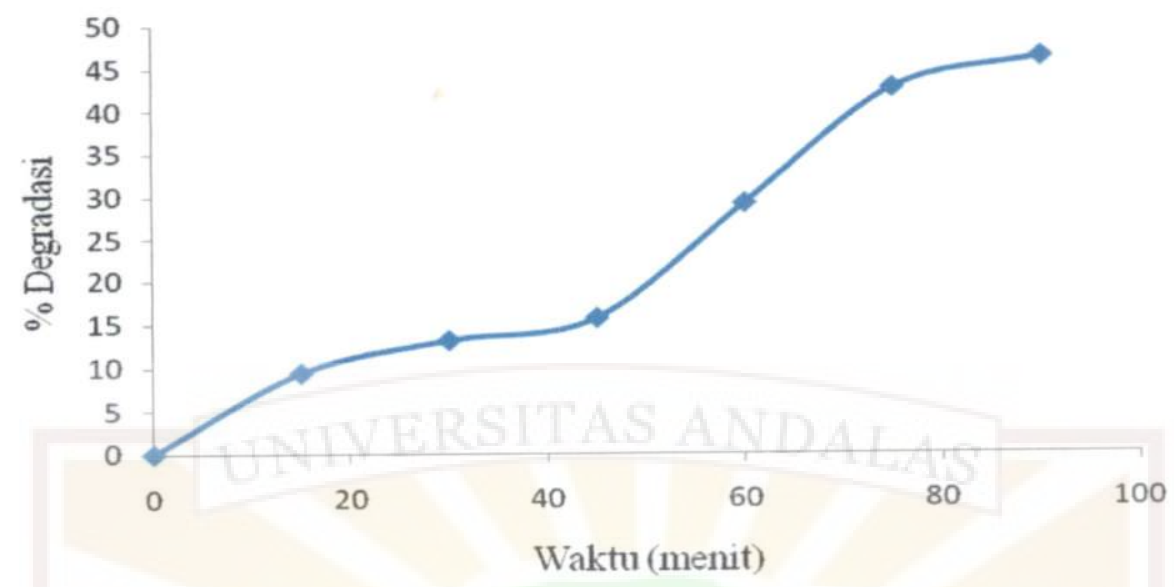

Gambar 9. Pengaruh waktu ozonolisis terhadap persen degradasi Carbaryl $20 \mathrm{mg} / \mathrm{L}$

(waktu 15, 30, 45, 60, 75, 90 menit )

Dari Gambar 9 terlihat bahwa persentase degradasi Carbaryl meningkat dengan bertambahnya waktu ozonolisis. Semakin lama waktu ozonolisis yang digunakan maka akan semakin besar persentase degradasi yang didapatkan. Pada Gambar 8 terlihat persentase degradasi tertinggi pada waktu 90 menit yaitu $46,17 \%$. Dengan bertambahnya waktu degradasi, ozon $\left(\mathrm{O}_{3}\right)$ dapat memproduksi radikal $\mathrm{OH}$ lebih banyak. Radikal $\mathrm{OH}$ dapat menyerang senyawa pestisida yang berada bukan hanya pada permukaan larutan saja, namun juga dapat menyerang senyawa yang berada dalam larutan ${ }^{26}$.

\subsection{Pengaruh Waktu Ozonolisis Terhadap Persen Degradasi Carbaryl dengan}

\section{Penambahan $\mathrm{SnO}_{2}$}

Larutan Carbaryl $20 \mathrm{mg} / \mathrm{L}$ yang telah ditambahkan dengan $10,0 \mathrm{mg} \mathrm{SnO}_{2}$ di ozonolisis masing-masingnya selama 15, 30, 45, 60, 75, 90 menit. Dari Gambar 4 dapat dilihat bahwa persen degradasi senyawa Carbaryl meningkat seiring bertambahnya waktu ozonolisis dengan penambahan katalis $\mathrm{SnO}_{2}$, sehingga pada menit ke 90 senyawa Carbaryl telah dapat didegradasi sebesar 56,72\%. Presentase degradasi senyawa Carbaryl dengan penambahan $\mathrm{SnO}_{2}$ dapat dilihat pada Gambar 10. 


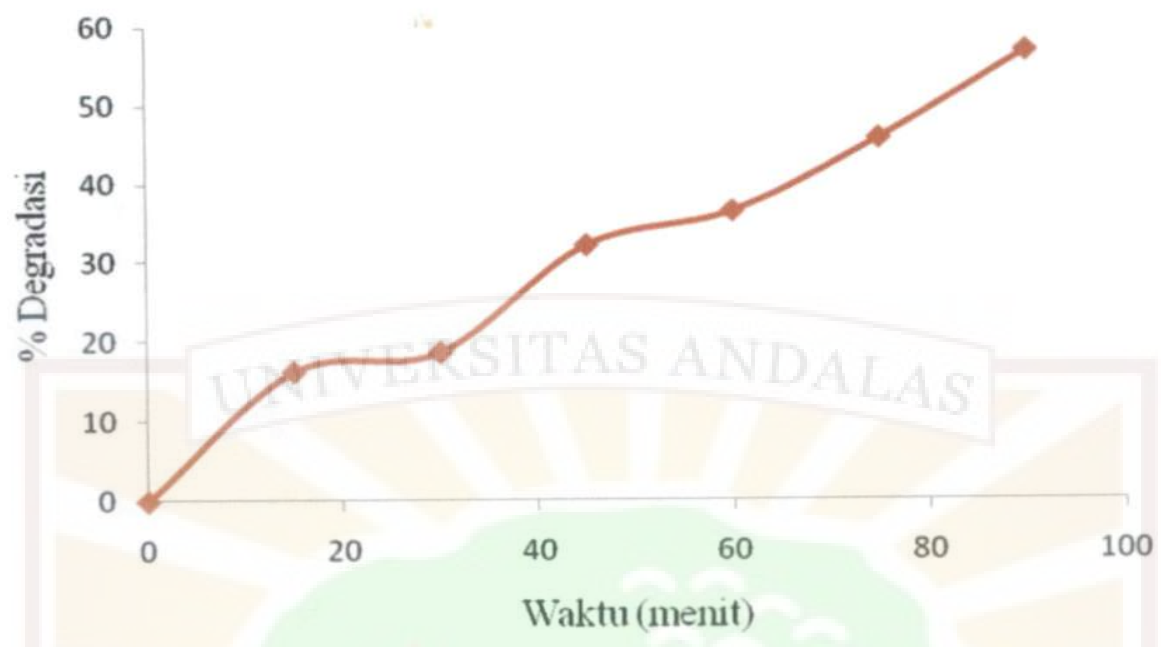

Gambar 10. Pengaruh waktu ozonolisis terhadap presentase degradasi Carbaryl dengan penambahan $\mathrm{SnO}_{2},[$ Carbaryl $] 20 \mathrm{mg} / \mathrm{L}, \mathrm{SnO}_{2} 0$ dan $10 \mathrm{mg}$.

Dari Gambar 10 terlihat bahwa persen degradasi Carbaryl akan lebih meningkat dengan bertambahnya waktu ozonolisis dengan penambahan katalis $\mathrm{SnO}_{2}$. Pengaruh penambahan $\mathrm{SnO}_{2}$ terhadap peningkatan degradasi disebabkan karena adanya pembentukan radikal $\mathrm{OH}$ pada permukaan $\mathrm{SnO}_{2}$. Dengan adanya penambahan radikal $\mathrm{OH}$ pada permukaan $\mathrm{SnO}_{2}$ akan membantu dalam peningkatan persen degradasi senyawa Carbaryl.

\subsection{Pengaruh Waktu Ozonolisis Terhadap Persen Degradasi Carbaryl dengan} Penambahan $\mathrm{TiO}_{2}$-anatase.

Larutan Carbaryl $20 \mathrm{mg} / \mathrm{L}$ yang masing-masingnya diozonolisis selama 15 , 30, 45, 60, 75, 90 menit, Selanjutnya ditambahkan dengan 10,0 mg $\mathrm{TiO}_{2}$-anatase. Dari Gambar 10 dapat dilihat bahwa persen degradasi senyawa Carbaryl meningkat seiring bertambahnya waktu ozonolisis dengan penambahan katalis $\mathrm{TiO}_{2}$-anatase, sehingga pada menit ke 90 senyawa Carbaryl telah terdegradasi sebesar $72,67 \%$. Presentase degradasi senyawa Carbaryl dengan penambahan $\mathrm{TiO}_{2}$-anatase dapat dilihat pada Gambar 11. 


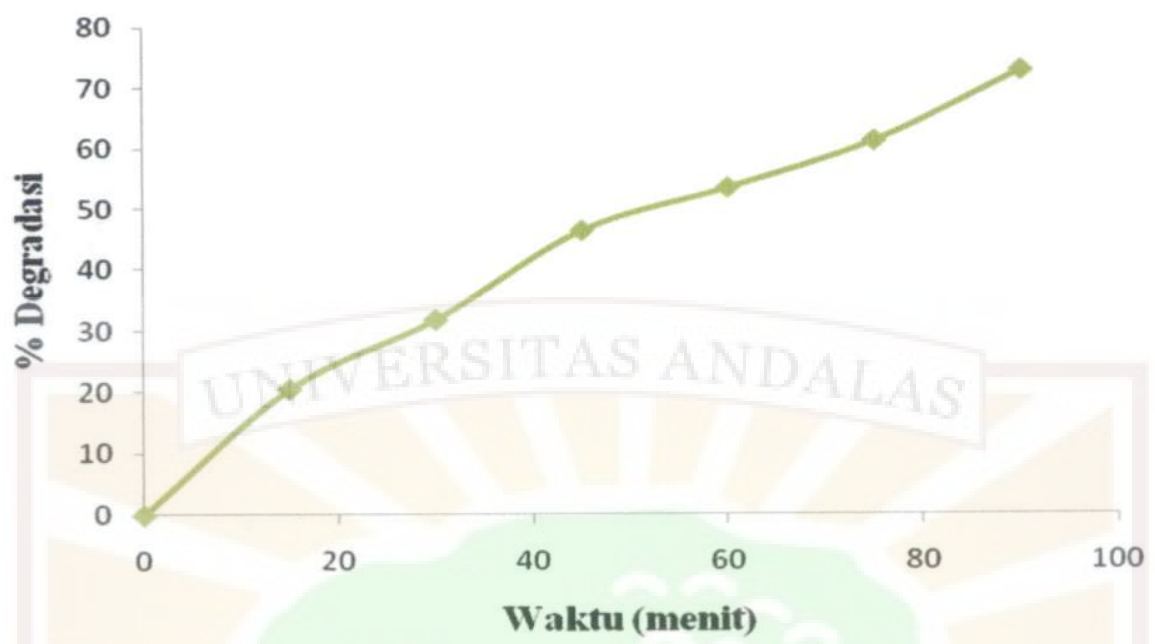

Gambar 11.Pengaruh waktu ozonolisis terhadap presentase degradasi Carbaryl dengan penambahan $\mathrm{TiO}_{2}$-anatase , $\left[\right.$ Carbaryl] $20 \mathrm{mg} / \mathrm{L}, \mathrm{TiO}_{2}$-anatase 0 dan $10 \mathrm{mg}$.

Dari Gambar 11 dapat dilihat, dengan adanya penambahan $\mathrm{TiO}_{2}$-anatase selama waktu ozonolisis berlangsung akan mempercepat proses degradasi senyawa Carbaryl. Peningkatan jumlah degradasi senyawa Carbaryl dengan penambahan $\mathrm{TiO}_{2}$-anatase disebabkan karena pembentukan radikal $\mathrm{OH}$ pada permukaan $\mathrm{TiO}_{2}$ anatase. Disamping itu, permukaan $\mathrm{TiO}_{2}$-anatase mempunyai kemampuan untuk menginisiasi reaksi kimia, dimana di dalam air kebanyakan senyawa organik dapat dioksidasi menjadi $\mathrm{CO}_{2}$ dan $\mathrm{H}_{2} \mathrm{O}^{15}$.

\subsection{Efektifitas Waktu Ozonolisis Tanpa Penambahan Katalis, Dengan} Penambahan Katalis $\mathrm{SnO}_{2}$ dan $\mathrm{TiO}_{2}$-anatase Dalam Mendegradasi Senyawa Carbaryl

Untuk melihat perbandingan metoda ozonolisis tanpa katalis, dengan penambahan katalis $\mathrm{SnO}_{2}$ dan $\mathrm{TiO}_{2}$-anatase, maka dilakukan pendegradasian dengan variasi waktu 15, 30, 45, 60, 75, 90 menit, yang dapat dilihat pada Gambar 12 . 


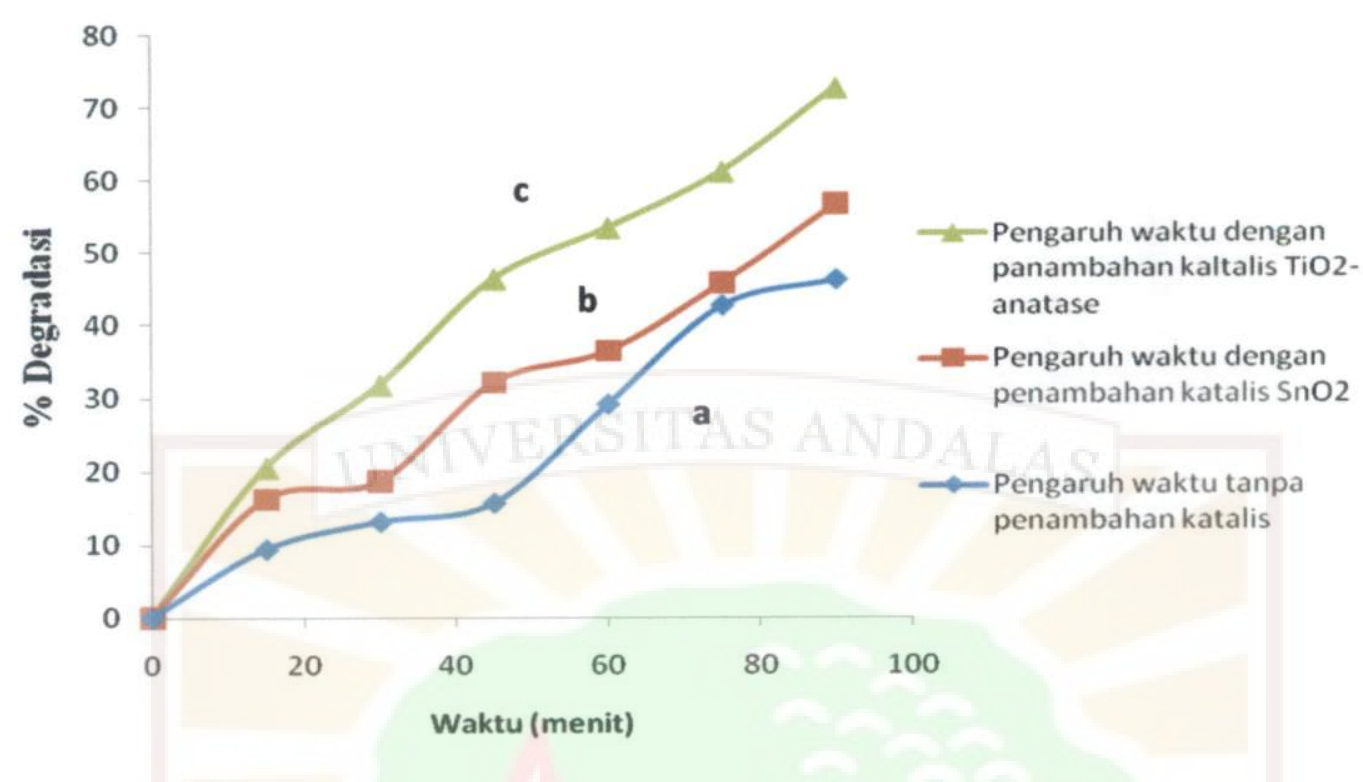

Gambar 12. Pengaruh waktu ozonolisis terhadap persen degradasi Carbaryl $20 \mathrm{mg} / \mathrm{L}$.

a) tanpa penambahan katalis, b) Dengan penambahan $\mathrm{SnO}_{2}$, c) dengan penambahan $\mathrm{TiO}_{2}$-anatase.

Dari Gambar 12 dapat dilihat bahwa yang paling berpengaruh terhadap persen degradasi Carbaryl adalah proses ozonolosis dengan penambahan $\mathrm{TiO}_{2}$-anatase, kemudian dilanjutkan dengan metoda ozonolisis dengan penambahan $\mathrm{SnO}_{2}$ dan tanpa penambahan katalis. Persen degradasi Carbaryl tertinggi terjadi pada waktu 90 menit dengan penambahan $\mathrm{TiO}_{2}$-anatase yaitu mencapai $72,67 \%$, sedangkan persen degradasi Carbaryl dengan penambahan $\mathrm{SnO}_{2}$ dan tanpa penambahan katalis pada waktu 90 menit terdegradasi sebanyak $56,72 \%$ dan $46,16 \%$.

Dari Gambar 12 dapat dikatakan persen degradasi meningkat dengan bertambahnya waktu degradasi. Selain itu dengan penambahan katalis selama proses degradasi berlangsung akan memperbesar pesen degradasi dari senyawa Carbaryl. Ini disebabkan karena dengan penambahan katalis selama proses degradasi akan membantu memperbanyak radikal $\mathrm{OH}$, yang nanti akan membantu dalam proses pendegradasian. 
Dari metoda ozonolisis yang dilakukan tanpa penambahan katalis, penambahan katalis $\mathrm{SnO}_{2}$ dan $\mathrm{TiO}_{2}$-anatase pada waktu optimum degradasi dapat dilihat perbandingan keefektifannya pada Tabel 2.

Tabel 2. Efektifitas metoda ozonolisis terhadap persen degradasi senyawa Carbaryl tanpa penambahan katalis, dengan penambahan katalis $\mathrm{SnO}_{2}$ dan $\mathrm{TiO}_{2}$-anatase pada waktu 90 menit.

\begin{tabular}{|c|c|c|c|}
\hline Metoda & $\begin{array}{c}\text { \% Degradasi } \\
\text { tanpa } \\
\text { penambahan } \\
\text { katalis }\end{array}$ & $\begin{array}{c}\% \text { Degradasi } \\
\text { dengan } \\
\text { penambahan } \\
\text { katalis } \mathrm{SnO}_{2} \text {. }\end{array}$ & $\begin{array}{c}\% \text { Degradasi } \\
\text { dengan } \\
\text { penambahan } \\
\text { katalis } \mathrm{TiO}_{2-} \\
\text { anatase }\end{array}$ \\
\hline Ozonolis & 46,16 & 56,72 & 72,6 \\
\hline
\end{tabular}

Dari Tabel 2 dapat dilihat perbandingan efektifitas dari metoda ozonolisis tanpa penambahan katalis, dengan penambahan katalis $\mathrm{SnO}_{2}$ dan $\mathrm{TiO}_{2}$-anatase. Dimana persen degradasi terbesar terjadi dengan penambahan katalis $\mathrm{TiO}_{2}$-anatase selama proses pendegradasian berlangsung yaitu sebesar $72,67 \%$.

Aktifitas dari katalis $\mathrm{TiO}_{2}$-anatase lebih bagus dibandingkan dengan katalis $\mathrm{SnO}_{2}$. Ini disebabkan karena $\mathrm{TiO}_{2}$-anatase mempunyai sifat yang lebih stabil dibandingkan dengan $\mathrm{SnO}_{2}$ dalam proses pendegradasian. Dengan penambahan katalis $\mathrm{TiO}_{2}$-anatase akan memperbanyak produksi radikal $\mathrm{OH}$ dibandingkan dengan penambahan katalis $\mathrm{SnO}_{2}$. Selain itu, $\mathrm{TiO}_{2}$-anatase mempunyai band gap yang lebih kecil dibandingkan dengan $\mathrm{SnO}_{2}$, sehingga penyerapan $\mathrm{TiO}_{2}$-anatase akan lebih bagus dan akan semakin mudah membentuk radikal $\mathrm{OH}$ pada permukaannya. $\mathrm{TiO}_{2}$ anatase mempunyai bentuk kristal antase sedangkan $\mathrm{SnO}_{2}$ membentuk kristal rutile. Dimana aktifitas kristal anatase lebih bagus dibandingkan kristal rutile. Semakin bagus aktifitas yang dimiliki suatu katalis semakin banyak radikal $\mathrm{OH}$ yang dihasilkan. Semakin banyak radikal $\mathrm{OH}$ yang dihasilkan semakin besar pula persen degradasi dari senyawa Carbaryl. 


\subsection{Spektrum Serapan Carbaryl setelah Ozonolisis}

Larutan Carbaryl awal dan setelah ozonolisis diukur spektrum serapannya pada panjang gelombang maksimum dengan Spektrofotometer UV-Vis. Larutan Carbaryl setelah ozonolisis dilakukan pengukuran spektrum serapannya pada kondisi optimum dengan penambahan $\mathrm{SnO}_{2}$ dan $\mathrm{TiO}_{2}$-anatase, ini bertujuan untuk membandingkan efektifitas kedua katalis dalam proses pendegradasian. Hasil pengukuran spektrum Carbaryl setelah ozonolis setelah penambahan $\mathrm{SnO}_{2}$ dan $\mathrm{TiO}_{2}$-anatase dapat dilihat pada Gambar 12 .

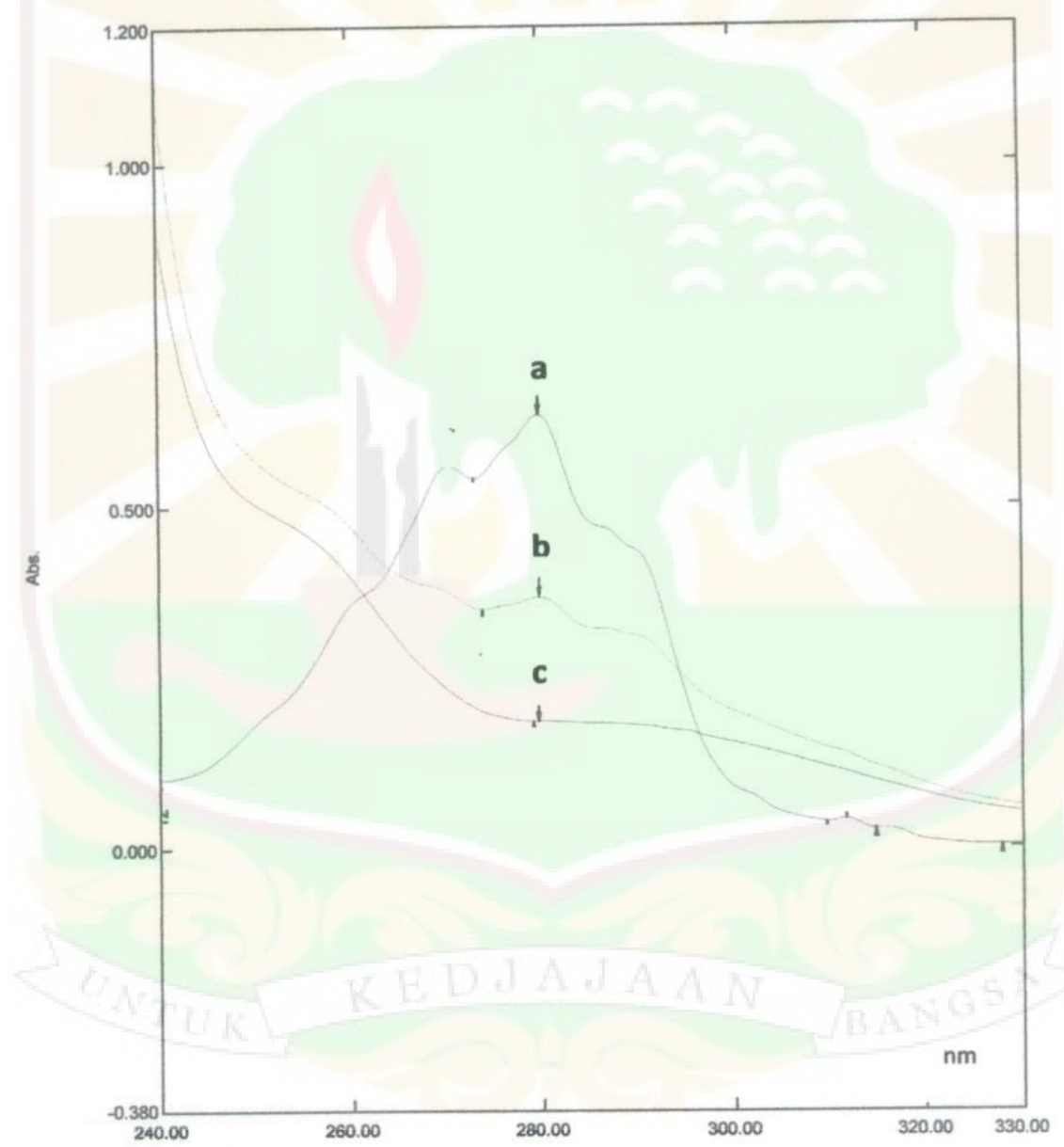

Gambar 13.Spektrum serapan Carbaryl pada waktu optimum dengan spektrofotometer UV-Vis. a) awal b) dengan penambahan $\mathrm{SnO}_{2}$ c) dengan penambahan $\mathrm{TiO}_{2}$-anatase. 
Dari Gambar 13 dapat dilihat penurunan spektrum serapan Carbaryl awal dan setelah degradasi berlangsung. Dari spektrum yang terdapat pada gambar 13 dapat dilihat tinggi spektrum awal lebih tinggi dari pada setelah ozonolisis dengan penambahan $\mathrm{SnO}_{2}$ dan $\mathrm{TiO}_{2}$-anatase. Setelah dilakukan ozonolisis dengan penambahan $\mathrm{SnO}_{2}$ dan $\mathrm{TiO}_{2}$-anatase maka spektrum sampel awal akan mengalami penurunan intensitas. Penurunan intensitas spektrum terbesar terjadi pada hasil ozonolisis dengan penambahan $\mathrm{TiO}_{2}$-anatase, ini disebabkan karena katalis $\mathrm{TiO}_{2}$-anatase mempunyai efektifitas dan aktifitas yang bagus dalam mendegradasi senyawa Carbaryl secara ozonolis. Selain itu $\mathrm{TiO}_{2}$-anatese mempunyai kemampuan yang lebih kuat dibandingkan dengan $\mathrm{SnO}_{2}$ dalam menghasilkan radikal $\mathrm{OH}$ pada permukaannya, sehingga radikal $\mathrm{OH}$ yang dihasilkan pada permukaan $\mathrm{TiO}_{2}$-anatase akan lebih banyak. Semakin banyak radikal $\mathrm{OH}$ yang dihasilkan maka akan semakin mudah suatu senyawa mengalami proses pendegradasian.

\subsection{Kromatogram Hasil Degradasi Carbaryl Secara Ozonolisis dengan menggunakan HPLC}

Analisis HPLC dilakukan untuk melihat perbandingan aktifitas katalis $\mathrm{SnO}_{2}$ dan $\mathrm{TiO}_{2}$-anatase dalam proses degradasi secara ozonolisis pada waktu optimum. Pada analisis HPLC ini dilakukan pengukuran sampel larutan Carbaryl awal, Sampel hasil ozonolisis dengan penambahan katalis $\mathrm{SnO}_{2}$ dan $\mathrm{TiO}_{2}$-anatase pada waktu optimum pendegradasian. Sampel yang diinjeksikan pada alat HPLC sebanyak $20 \mu \mathrm{L}$. Kondisi HPLC dengan mengunakan fase gerak metanol : air ( $3 \mathrm{ml}: 2 \mathrm{ml})$, laju alir $1 \mathrm{ml} /$ menit dan panjang gelombang $280 \mathrm{~nm}$. Sampel yang diinjeksikan adalah sampel larutan awal Carbaryl, hasil degradasi secara ozonolis pada waktu 90 menit dengan penambahan katalis $\mathrm{SnO}_{2}$ dan $\mathrm{TiO}_{2}$-anatase. Sebelumnya fase gerak yang digunakan pada HPLC harus didegassing terlebih dahulu dengan tujuan untuk menghilangkan gelembungan udara yang dapat menganggu proses analisa. Sampel yang diinjeksikan ke alat HPLC harus disaring terlebih dahulu dengan membran filter, tujuannya untuk memisahkan pengganggu atau katalis yang masih tertinggal selama proses degradasi. 
Hasil pengukran HPLC larutan sampel awal larutan Carbaryl, hasil ozonolisis dengan penambahan katalis $\mathrm{SnO}_{2}$ dan $\mathrm{TiO}_{2}$-anatase pada waktu optimum pendegradasian dapat dilihat pada Gambar 14.

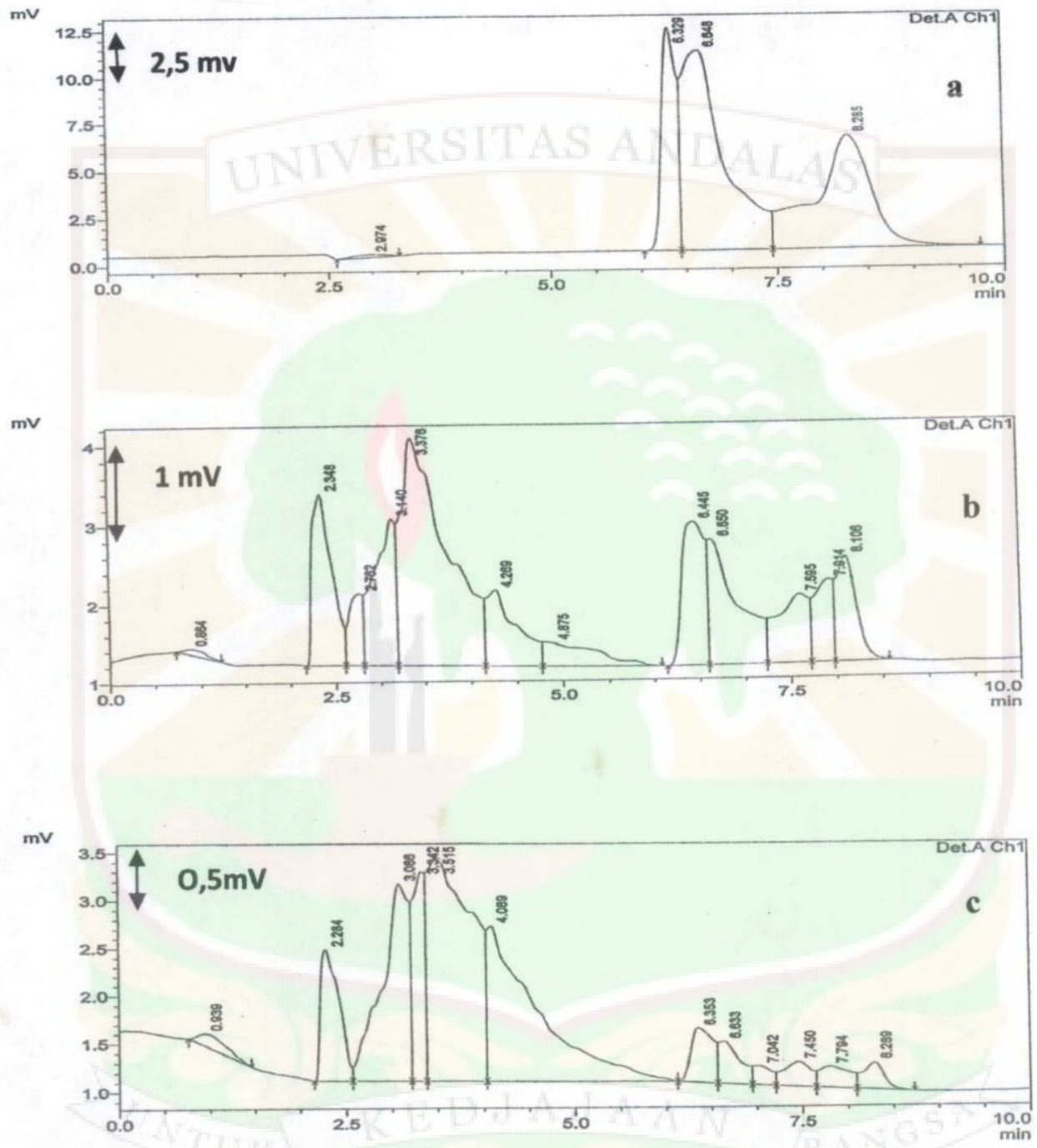

Gambar 14. Hasil Pengukuran Carbaryl Pada Waktu Optimum dengan HPLC. a) awal, b) setelah penambahan $\mathrm{SnO}_{2}$, c) setelah penambahan $\mathrm{TiO}_{2}$ anatase. ( Fase gerak: metanol : air (3:2), Volume injeksi: $20 \mu \mathrm{L}$, Laju alir: $1 \mathrm{ml} /$ menit, Detektor: UV, Panjang gelombang: $280 \mathrm{~nm}$, Temperatur: $40{ }^{\circ} \mathrm{C}$, Kolom: $\mathrm{C}_{18}$ (Shim-pack VP-ODS) $250 \times 4,6 \mathrm{~mm}$ id) 
Dari Gambar 14 dapat dilihat bahwa pada masing-masing perlakuan terdapat lebih dari satu puncak kromatogram, ini disebabkan karena Carbaryl yang terkandung didalam sampel hanya terdapat $85 \%$.

Dari Kromatogram yang terdapat pada Gambar 14 dapat dilihat tinggi kromatogram awal lebih tinggi dari setelah ozonolisis dengan penambahan $\mathrm{SnO}_{2}$ dan $\mathrm{TiO}_{2}$-anatase. Setelah dilakukan ozonolisis dengan penambahan $\mathrm{SnO}_{2}$ dan $\mathrm{TiO}_{2}$-anatase maka puncak dari kromatogram sampel awal akan mengalami penurunan intensitas dan memngalami pemecahan puncak-puncak kromatogram. Penurunan intensitas terbesar terjadi pada hasil ozonolisis dengan penambahan $\mathrm{TiO}_{2}$-anatase, ini disebabkan karena katalis $\mathrm{TiO}_{2}$-anatase mempunyai efektifitas yang bagus dalam mendegradasi senyawa Carbaryl secara ozonolisis. 


\section{BAB V}

\section{KESIMPULAN DAN SARAN}

\subsection{Kesimpulan.}

Dari penelitian yang telah dilakukan dapat disimpulkan bahwa katalis $\mathrm{SnO}_{2}$ dan $\mathrm{TiO}_{2}$-anatase dapat digunakan untuk mendegradasi pestisida Carbaryl secara ozonolisis. Metoda ozonolisis tanpa penambahan katalis menghasilkan persentase degradasi sebesar 46,17\% selama 90 menit. Degradasi Carbaryl secara ozonolisis dengan penambahan $\mathrm{SnO}_{2}$ dan $\mathrm{TiO}_{2}$-anatase setelah 90 menit didapatkan persen degradasi sebesar 56,72\% dan $72,67 \%$. Dari hasil degradasi dapat dilihat bahwa katalis $\mathrm{TiO}_{2}$-anatase mempunyai efektifitas yang lebih bagus dibadingkan katalis $\mathrm{SnO}_{2}$ di dalam mendegradasi pestisida Carbaryl secara ozonolisis. Pengukuran senyawa Carbaryl menggunakan HPLC didapatkan beberapa puncak kromatogram untuk masing-masing perlakuan degradasi. Puncak-puncak tersebut selain senyawa Carbaryl, juga terdapat intermediet dari senyawa Carbaryl.

\subsection{Saran}

Untuk mengetahui senyawa hasil degradasi Carbaryl secara ozonolisis dengan penambahan $\mathrm{SnO}_{2}$ dan $\mathrm{TiO}_{2}$-anatase disarankan untuk melakukan identifikasi menggunakan HPLC-MS. Selain itu, untuk mendapatkan pemisahan yang bagus disarankan memilih fase gerak dan fase diam yang cocok untuk pemisahan. 


\section{DAFTAR PUSTAKA}

1. Sudarmono, S, Pestisida, Kanius, Yogyakarta, 1991.

2. L.F Tietze, M. Bratz. Ozonololysis Mechanism in Organic, Org Synth Coll, 9 : 34, 1998.

3. Xu, Xian-wen, S. Hui-xiang, W. Da-hui, Ozonation with ultrasonic enhancement of p-nitrophenol wastewater. J. Zhejiang Univ Science B.5 : 319-323, 2005.

4. S. Arief, Safni dan P. Roza, Degradasi Senyawa Rhodamin B secara Sonolisis dengan penambahan $\mathrm{TiO}_{2}$-anatase Hasil Sintesa Melalui Proses Sol-gel, J.Ris Kim. 1 (1),64-69, 2007.

5. Safni, U. Loekman dan F. Febrianti, Degradasi senyawa Sudan I secara sonolisis dan fotolisis dengan penambahan $\mathrm{TiO}_{2}$-anatase, J.Ris Kim.2 (1),164-169, 2008.

6. Safni, Maizatisna, dan Zulfarman, Degradasi zat warna Naphthol Blue Black secara Sonolisis dan fotolisis dengan penambahan $\mathrm{TiO}_{2}$-anatase Hasil Sintesa Melalui Proses Sol-gel, J.Ris Kim.1 (1).43-49, 2007.

7. . Safni, Z. Zuki, C. Haryati, dan Maizatisna, Degradasi zat warna alizarin secara sonolisis dan fotolisis dengan penambahan $\mathrm{TiO}_{2}$-anatase. J. Pilar. J.Ris Kim.2 (1), 2008.

8. Riza, VT. Dan Gayatri, Inggatlah Bahaya Pestisida, Bunga Rampai Residu Pestisida dan Alternatifnya. Pestisida. Action Net Work ( PAN ) Jakarta, 1994.

9. Lasut, M. T. P. Bobby dan A. K Veronaki. Komplikasi Tingkat Toksisitas Beberapa Pestisida ( Endosulan, Fentoat, BPMC, Paraquat) Dengan menggunakan Ikan Bandeng ( Chanos Chanos Forsk). Hasil penelitian Universitas Sam Ratulangi. Manado, 2001.

10. M. Kanan, A Study of The Photodegradation of Carbaryl: The Influence of Natural Organic Matter and The Use of Silver Zeolite $Y$ as a Catalyst. The University of Maine, Thesis, 2001.

11.Vogelpohl, A. and S.Kim, Advanced Oxidation Processes (AOPs) in Wastewater Treatment, J. Ind. Eng. Chem, 10 : ( 1 ), 33-44, 2004.

12. Goncalves, Alex Augusto. Ozone-An Emerging Technology for The Seafood Industry. Brazilian Archives of Biology and Technology . ( BD-2134), 2008.

13. Wu, Jigau, Removal of Residual Pesticides on Vegetable Using Ozanated Water. Sun Yet-Sen University, 135 Xinggangxi Road, Guangzhou 510275, PR China. 
14. Akhiruddin Maddu, Rod Tua, Mersi kurniati, Penumbuhan Film Nanokristal $\mathrm{SnO}_{2}$ dengan Metode Chemical Bath Deposition (CBD), J.Nanosains dan . Teknologi, (8), 2009.

15. Fujishima, A. K, T. N. Rao dan D. A. Tryk, Titanium Dioxide Photocatalys, J. Photochemistry and Photobiology C. Photochemistry Review, 1-21, 2000.

16. J. Gunlazardi, Fotokatalisis Pada permukaan TiO2 : Anspek Fundamentalik dan Aplikasinya, Seminar Nasional Kimia Fisika II, Jurusan Kimia FMIPA UI, Depok, 2001.

17. Kameyama, T, Science and Technology for Safe and Secure Life Space. Photocatatalist, Ainst s Photocatalyst, 2002.

18. Park, H, W, Choi, Photocatalytic Reactivities of Nafion-Coated $\mathrm{TiO}_{2}$ for The Degradation Charged Organic Coumpounds under UV or Visible Light, J. Phys. Chem. B. 109. 11667-11674, 2005.

19. Khopkar, S.M, Konsep Dasar Kimia Analitik, Hal 168, UI Press, 1990.

20. Underwood, A.L, R. A. Day, Analisis Kimia Kuantitatif, Terjemahan Handayana, Pujdaatmaka, Edisi Keenam, Erlangga, Jakarta : pp. 384-422, 2002

21. Gritter, R. J, J. M. Bobbit and E.S. Arthur, Intoduction to Chromatography, Terjemahan oleh Kasasih Padmawita, Edisi ke-2, Penerbit ITB, Bandung, 1991

22. Skoog, D.A, Principles of Instrumental Analysis, $3^{\text {rd }}$ ed, Sounders Golden sumburst series, New York, 1985.

23. Poole, C. F, and S. K. Poole, Choromatography today, $1^{\text {st }}$ ed, Elsevier science B. V, Netherlands, 1994.

24. Barcelo, D. and M.C. Hennion, On-line Sample handling strategies for trace level determination of pesticides and their degradation product in environmental waters, Anal. Chim. Acta, 318: 2-4, 1995.

25. Jhonson, L. Edward, Robert Stevenson, Dasar Kromatografi Cair, ITB Press, Bandung, 1991.

26. Ruan, R, Z. Liu, S. Deng, Removal of Pesticides Residue in produce with Ozonated Water Wash, CIGR Internasional Conference Beijing, 2004.

27. Safni, Sri Rezki Nofriani, Hamzar Suyani, "Degradation of carbaryl contained in pesticide Sevin $85 \mathrm{~S}$ by photolysis method with addition of $\mathrm{TiO}_{2}$ anatase," J. Dampak 6 (2), 19-23, 2009. 


\section{Lampiran 1. Perhitungan penentuan absorbtivitas Molar ( $(\varepsilon)$}

Tabel 3. Data absorban Carbaryl pada variasi konsentrasi

\begin{tabular}{|c|c|}
\hline Konsentrasi $(\mathrm{mg} / \mathrm{L})$ & Absorban (A) \\
\hline 10 & 0,314 \\
\hline 20 & 0,612 \\
\hline 30 & 0,918 \\
\hline 40 & 1,309 \\
\hline 50 & 1,606 \\
\hline
\end{tabular}

Rumus : $\varepsilon=\frac{A}{b \times c} \times M r$

Dimana :

$\mathrm{A}=$ Absorban

$\mathrm{b}=$ Lajur larutan $(\mathrm{cm})$

c $=$ Konsentrasi $\left(\mathrm{g} \mathrm{L}^{-1}\right)$

$\varepsilon=$ Absorbtivitas molar $\left(\mathrm{L} \mathrm{mol}^{-1} \mathrm{~cm}^{-1}\right)$

$\mathrm{Mr}=$ Massa molekul relatif $\left(\mathrm{g} \mathrm{mol}^{-1}\right)$

- Untuk konsentrasi larutan carbaryl $10 \mathrm{mg} / \mathrm{L}$

$$
\varepsilon=\frac{0,314}{1 \mathrm{~cm} \times 0,01 \mathrm{~g} / \mathrm{L}} \times 201,23^{\mathrm{g}} / \mathrm{mol}=6318,622 \mathrm{~L} \mathrm{~mol}^{-1} \mathrm{~cm}^{-1}
$$

- Untuk konsentrasi larutan carbaryl $20 \mathrm{mg} / \mathrm{L}$

$$
\varepsilon=\frac{0,612}{1 \mathrm{~cm} \times 0,02 \mathrm{~g} / \mathrm{L}} \times 201,23^{\mathrm{g}} / \mathrm{mol}=6157,638 \mathrm{~L} \mathrm{~mol}^{-1} \mathrm{~cm}^{-1}
$$

- Untuk konsentrasi larutan carbaryl $30 \mathrm{mg} / \mathrm{L}$

$$
\varepsilon=\frac{0,918}{1 \mathrm{~cm} \times 0,03 \mathrm{~g} / \mathrm{L}} \times 201,23^{\mathrm{g}} / \mathrm{mol}=6157,638 \mathrm{~L} \mathrm{~mol}^{-1} \mathrm{~cm}^{-1}
$$

- Untuk konsentrasi larutan carbaryl $40 \mathrm{mg} / \mathrm{L}$

$$
\varepsilon=\frac{1,309}{1 \mathrm{~cm} \times 0,04 \mathrm{~g} / \mathrm{L}} \times 201,23^{\mathrm{g}} / \mathrm{mol}=6585,2518 \mathrm{~L} \mathrm{~mol}^{-1} \mathrm{~cm}^{-1}
$$


- Untuk konsentrasi larutan carbaryl $50 \mathrm{mg} / \mathrm{L}$

$\varepsilon=\frac{1,606}{1 \mathrm{~cm} \times 0,05 \mathrm{~g} / \mathrm{L}} \times 201,23^{\mathrm{g}} / \mathrm{mol}=6463,5076 \mathrm{~L} \mathrm{~mol}^{-1} \mathrm{~cm}^{-1}$

absorbtivitas Molar $(\varepsilon)$ rata-rata :

$$
\begin{aligned}
& =\frac{(6318,622+6157,638+6157,638+6585,2518+6463,5076) \mathrm{L} \mathrm{mol}^{-1} \mathrm{~cm}^{-1}}{5} \\
& =6336,53148 \mathrm{~L} \mathrm{~mol}^{-1} \mathrm{~cm}^{-1}
\end{aligned}
$$




\section{Lampiran 2. Data absorban dan perhitungan persentase degradasi Carbaryl} $20 \mathrm{mg} / \mathrm{L}$ berdasarkan pengaruh waktu ozonolisis .

Tabel 4. Data absorban dan persentase degradasi Carbaryl $20 \mathrm{mg} / \mathrm{L}$ berdasarkan pengaruh waktu ozonolisis

\begin{tabular}{|c|c|c|c|}
\hline $\begin{array}{c}\text { Waktu } \\
\text { (menit) }\end{array}$ & $\begin{array}{c}\text { Absorban } \\
\text { Awal }\end{array}$ & $\begin{array}{c}\text { Absorban } \\
\text { Akhir }\end{array}$ & \% Degradasi \\
\hline 0 & 0,587 & 0,587 & 0 \\
\hline 15 & 0,587 & 0,532 & 9,37 \\
\hline 30 & 0,587 & 0,510 & 13,12 \\
\hline 45 & 0,587 & 0,495 & 15,67 \\
\hline 60 & 0,587 & 0,416 & 29,13 \\
\hline 75 & 0,587 & 0,337 & 42,59 \\
\hline 90 & 0,587 & 0,316 & 46,17 \\
\hline
\end{tabular}

$$
\text { Persen degradasi }=\frac{\mathrm{A}_{\text {awal }}-\mathrm{A}_{\text {akhir }}}{\mathrm{A}_{\text {awal }}} \times 100 \%
$$

- Ozonolisis carbaryl $20 \mathrm{mg} / \mathrm{L}$ selama 15 menit

$$
\% \text { Degradasi }=\frac{0,587-0,532}{0,587} \times 100 \%=9,3697 \%=9,37 \%
$$

- Ozonolisis carbaryl $20 \mathrm{mg} / \mathrm{L}$ selama 30 menit

$$
\% \text { Degradasi }=\frac{0,587-0,510}{0,587} \times 100 \%=13,1175 \%=13,12 \%
$$

- Ozonolisis carbaryl $20 \mathrm{mg} / \mathrm{L}$ selama 45 menit

$$
\% \text { Degradasi }=\frac{0,587-0,495}{0,587} \times 100 \%=15,6729 \%=15,67 \%
$$

- Ozonolisis carbaryl $20 \mathrm{mg} / \mathrm{L}$ selama 60 menit

$$
\% \text { Degradasi }=\frac{0,587-0,416}{0,587} \times 100 \%=29,1312 \%=29,13 \%
$$


- Ozonolisis carbaryl $20 \mathrm{mg} / \mathrm{L}$ selama 75 menit $\%$ Degradasi $=\frac{0,587-0,337}{0,587} \times 100 \%=45,5894 \%=45,59 \%$

- Ozonolisis carbaryl $20 \mathrm{mg} / \mathrm{L}$ selama 90 menit

$$
\% \text { Degradasi }=\frac{0,587-0,316}{0,587} \times 100 \%=46,1670 \%=46,17 \%
$$




\section{Lampiran 3. Data absorban dan perhitungan persentase degradasi Carbaryl} $20 \mathrm{mg} / \mathrm{L}$ berdasarkan pengaruh waktu ozonolisis dengan penambahan $10,0 \mathrm{mg} \mathrm{SnO}$.

Tabel 5. Data absorban dan persentase degradasi Carbaryl $20 \mathrm{mg} / \mathrm{L}$ berdasarkan pengaruh waktu ozonolisis dengan penambahan $10,0 \mathrm{mg} \mathrm{SnO}_{2}$

\begin{tabular}{|c|c|c|c|}
\hline $\begin{array}{c}\text { Waktu } \\
\text { (menit })\end{array}$ & $\begin{array}{c}\text { Absorban } \\
\text { Awal }\end{array}$ & $\begin{array}{c}\text { Absorban } \\
\text { Akhir }\end{array}$ & \% Degradasi \\
\hline 0 & 0,536 & 0,536 & 0 \\
\hline 15 & 0,536 & 0,449 & 16,23 \\
\hline 30 & 0,536 & 0,436 & 18,66 \\
\hline 45 & 0,536 & 0,364 & 32,09 \\
\hline 60 & 0,536 & 0,341 & 36,38 \\
\hline 75 & 0,536 & 0,291 & 45,71 \\
\hline 90 & 0,536 & 0,232 & 56,72 \\
\hline
\end{tabular}

$$
\text { Persen degradasi }=\frac{\mathrm{A}_{\text {awal }}-\mathrm{A}_{\text {akhir }}}{\mathrm{A}_{\text {awal }}} \times 100 \%
$$

- Ozonolisis carbaryl $20 \mathrm{mg} / \mathrm{L}$ selama 15 menit

$$
\% \text { Degradasi }=\frac{0,536-0,449}{0,536} \times 100 \%=16,2313 \%=16,23 \%
$$

- Ozonolisis carbaryl $20 \mathrm{mg} / \mathrm{L}$ selama 30 menit

$$
\% \text { Degradasi }=\frac{0,536-0,436}{0,536} \times 100 \%=18,6567 \%=18,66 \%
$$

- Ozonolisis carbaryl $20 \mathrm{mg} / \mathrm{L}$ selama 45 menit

$$
\% \text { Degradasi }=\frac{0,536-0,364}{0,536} \times 100 \%=32,0896 \%=32,09 \%
$$


- Ozonolisis carbaryl $20 \mathrm{mg} / \mathrm{L}$ selama 60 menit

$$
\% \text { Degradasi }=\frac{0,536-0,341}{0,536} \times 100 \%=36,3806 \%=36,38 \%
$$

- Ozonolisis carbaryl $20 \mathrm{mg} / \mathrm{L}$ selama 75 menit

$$
\% \text { Degradasi }=\frac{0,536-0,291}{0,536} \times 100 \%=45,7090 \%=45,71 \%
$$

- Ozonolisis carbaryl $20 \mathrm{mg} / \mathrm{L}$ selama 90 menit

$$
\% \text { Degradasi }=\frac{0,536-0,232}{0,536} \times 100 \%=56,7164 \%=56,72 \%
$$


Lampiran 4. Data absorban dan perhitungan persentase degradasi Carbaryl $20 \mathrm{mg} / \mathrm{L}$ berdasarkan pengaruh waktu ozonolisis dengan penambahan $10,0 \mathrm{mg} \mathrm{TiO}_{2}$-anatase.

Tabel 6. Data absorban dan persentase degradasi Carbaryl $20 \mathrm{mg} / \mathrm{L}$ berdasarkan pengaruh waktu ozonolisis dengan penambahan $10,0 \mathrm{mg} \mathrm{TiO}{ }_{2}$-anatase.

\begin{tabular}{|c|c|c|c|}
\hline $\begin{array}{c}\text { Waktu } \\
\text { (menit })\end{array}$ & $\begin{array}{c}\text { Absorban } \\
\text { Awal }\end{array}$ & $\begin{array}{c}\text { Absorban } \\
\text { Akhir }\end{array}$ & \% Degradasi \\
\hline 0 & 0,633 & 0,633 & 0 \\
\hline 15 & 0,633 & 0,503 & 20,54 \\
\hline 30 & 0,633 & 0,432 & 31,75 \\
\hline 45 & 0,633 & 0,340 & 46.29 \\
\hline 60 & 0,633 & 0,295 & 53,40 \\
\hline 75 & 0,633 & 0,246 & 61,14 \\
\hline 90 & 0,633 & 0,173 & 72,67 \\
\hline
\end{tabular}

Persen degradasi $=\frac{\mathrm{A}_{\text {awal }}-\mathrm{A}_{\text {akhir }}}{\mathrm{A}_{\text {awal }}} \times 100 \%$

- Ozonolisis carbaryl $20 \mathrm{mg} / \mathrm{L}$ selama 15 menit

$$
\% \text { Degradasi }=\frac{0,633-0,503}{0,633} \times 100 \%=20,5371 \%=20,54 \%
$$

- Ozonolisis carbaryl $20 \mathrm{mg} / \mathrm{L}$ selama 30 menit

$$
\% \text { Degradasi }=\frac{0,633-0,432}{0,633} \times 100 \%=31,7536 \%=31,75 \%
$$

- Ozonolisis carbaryl $20 \mathrm{mg} / \mathrm{L}$ selama 45 menit

$\%$ Degradasi $=\frac{0,633-0,340}{0,633} \times 100 \%=46,2875 \%=46,29 \%$ 
- Ozonolisis carbaryl $20 \mathrm{mg} / \mathrm{L}$ selama 60 menit

$$
\% \text { Degradasi }=\frac{0,633-0,295}{0,633} \times 100 \%=53,3965 \%=53,40 \%
$$

- Ozonolisis carbaryl $20 \mathrm{mg} / \mathrm{L}$ selama 75 menit

$$
\% \text { Degradasi }=\frac{0,633-0,246}{0,633} \times 100 \%=61,1374 \%=61,14 \%
$$

- Ozonolisis carbaryl $20 \mathrm{mg} / \mathrm{L}$ selama 90 menit

$$
\% \text { Degradasi }=\frac{0,633-0,173}{0,633} \times 100 \%=72,6698 \%=72,67 \%
$$

